\title{
ОСОБЛИВОСТІ МЕДИЧНОГО СТРАХУВАННЯ В УКРАЇНІ У СУЧАСНИХ УМОВАХ
}

\author{
Тернопільський національний медичний університет \\ імені І. Я. Горбачевського МОЗ України, м. Тернопіль, Україна
}

\begin{abstract}
Мета: з'ясувати особливості медичного страхування в сучасних умовах з урахуванням захворюваності населення.
Матеріали і методи. Використано наукові статті вітчизняних і закордонних науковців, довідники Державної служби статистики України, звітні матеріали Центру громадського здоров'я МОЗ України та Міністерства охорони здоров'я України. Під час виконання даного дослідження використано методи структурування, аналізу та узагальнення інформації.

Результати. У статті здійснено систематизацію наукових підходів щодо розуміння сутності категорії «медичне страхування». Для цього проведено аналіз нормативно-правової бази, що забезпечує регулювання медичного страхування в Україні, а також вивчення наукової літератури. На основі цього аналізу ссрормовано комплексне визначення категорії «медичне страхування». Визначено об'єкт, предмет і суб'єкт страхової діяльності. Окреслено основні особливості обов'язкового та добровільного медичного страхування. Наведено основні групи фракторів ризику, які впливають на стан здоров'я населення: соціально-економічні індикатори розвитку економіки; стан екології; рівень розвитку охорони здоров'я та ризики, пов'язані з розповсюдженістю окремих захворювань і смертністю від них. На основі дослідження виявлено основні проблеми розвитку медичного страхування: недосконалість нормативно-правового регулювання, нерівномірний розподіл коштів та недостатній рівень надання медичної допомоги.

Висновки. Сьогодні система охорони здоров'я нашої країни перебуває не лише у фінансовій, але й в організаційній кризі, що спричинена нерівномірним розподілом коштів та недостатнім рівнем надання медичної допомоги. Кроком до розв'язання проблем, що були означені у системі медичного забезпечення, може виступити проведення медичної реформи i, зокрема, впровадження загальнообов'язкового медичного страхування.
\end{abstract}

КЛЮчОВІ СЛОВА: медичне страхування; обов'язкове медичне страхування; добровільне медичне страхування; ринок медичного страхування.

Стан здоров'я населення, зумовлений багатьма показниками, є найважливішою характеристикою рівня соціально-економічного розвитку країни і впливає також на національну безпеку держави.

У сучасних умовах пандемії COVID-19 зростає актуальність врахування рівня захворюваності населення в процесі розробки рекомендацій 3 вдосконалення системи медичного страхування.

Проблематика, що стосується формування та розвитку системи медичного страхування в ринкових умовах, опрацьована закордонними і вітчизняними науковцями. Серед них потрібно виділити Н. Внукова, О. Вороніна, Т. Григора, Л. Временко, Н. Нагайчук, В. Стеценко, Т. Стецюк, В. Успаленко та ін.

Аналіз системи медичного страхування та проблем її розвитку в Україні проведено в роботах вітчизняних вчених М. Бас-Юрчишин, Т. Борисова, Є. Дяченко, С. Зайчук, В. Лисенко, С. Ніколаєнко, Л. Пархета, О. Світлична, С. Сокирко, Т. Стецюк, Ю. Шевчук, Л. Шупа, К. Штепенко та ін. Утім, незважаючи на значну кількість наукових праць, присвячених означеному питанню, дослідження

(c) Н. Я. Климук, 2021 вимагають актуальні дані про сучасний стан медичного страхування та його особливості 3 урахуванням захворюваності населення.

Мета дослідження: з'ясувати особливості медичного страхування в сучасних умовах з урахуванням захворюваності населення.

Матеріали і методи. Матеріалами для дослідження стали наукові статті вітчизняних і закордонних науковців, довідники Державної служби статистики України, звітні матеріали Центру громадського здоров'я МО3 України та Міністерства охорони здоров'я України. Під час виконання даного дослідження використано методи структурування, аналізу та узагальнення інформації.

Результати дослідження та їх обговорення. У процесі вивчення наукової літератури ми проаналізували різні визначення медичного страхування (табл. 1).

На основі проведеного аналізу можемо підсумувати, що в науковій літературі на даний момент відсутнє однозначне трактування сутності медичного страхування. На нашу думку, досить доступно сутність медичного страхування відображає таке пояснення: вид особистого 
Таблиця 1. Авторські тлумачення поняття «медичне страхування»

\begin{tabular}{|c|c|}
\hline Автор & Визначення \\
\hline $\begin{array}{l}\text { Ю. Т. Ахвледіані } \\
\text { і В. В. Шахов }\end{array}$ & $\begin{array}{l}\text { сукупність видів страхування на випадок втрати здоров'я через хворобу або нещасний } \\
\text { випадок, що передбачають обов'язки страховика зі здійснення страхових виплат, які } \\
\text { компенсують додаткові витрати застрахованого, викликані зверненням до медичної } \\
\text { установи за медичними послугами, включеними в програму страхування [14] }\end{array}$ \\
\hline Н. М. Внукова & $\begin{array}{l}\text { фрорма соціального захисту населення щодо охорони здоров'я, пов'язана з компенсацією } \\
\text { витрат громадян на медичне обслуговування [11] }\end{array}$ \\
\hline Д. Д. Третяк & $\begin{array}{l}\text { одна з форм соціального захисту населення у сорері охорони здоров'я, сутність якої } \\
\text { полягає в гарантуванні оплати послуг медичного характеру, отриманих застрахованою } \\
\text { особою, за рахунок акумульованих страхових коштів [15] }\end{array}$ \\
\hline О. К. Шихов & $\begin{array}{l}\text { сукупність страхових відносин, які передбачають, відповідно до закону і договору (правил) } \\
\text { страхування, обов'язки страховика щодо організації та повної або часткової оплати } \\
\text { вартості медичної допомоги, наданої застрахованій особі при настанні страхового випадку } \\
\text { [16] }\end{array}$ \\
\hline І. П. Хомініч & $\begin{array}{l}\text { вид страхування, що містить широкий перелік покриттів, які поширюються практично на } \\
\text { будь-які види витрат, пов'язаних з амбулаторним або стаціонарним лікуванням, а також зі } \\
\text { супутніми послугами, наданими застрахованій особі [13] }\end{array}$ \\
\hline $\begin{array}{l}\text { Л. О. Орланюк- } \\
\text { Маліцька }\end{array}$ & $\begin{array}{l}\text { сукупність видів особистого страхування, які передбачають компенсацію матеріальних } \\
\text { втрат і витрат застрахованих осіб, пов'язаних із відновленням здоров'я [12] }\end{array}$ \\
\hline $\begin{array}{l}\text { Л. Ф. Волохова і } \\
\text { Д. О. Остапенко }\end{array}$ & $\begin{array}{l}\text { один із видів особистого страхування, що здійснюється на випадок втрати здоров'я людини } \\
\text { та забезпечує отримання медичної допомоги за рахунок накопичених коштів, а також } \\
\text { фрінансування профрілактичних медичних заходів у разі настання страхового випадку [2] }\end{array}$ \\
\hline В. Д. Базилевич & $\begin{array}{l}\text { фрорма особового страхування, що гарантує громадянам отримання медичної допомоги } \\
\text { при настанні страхової події за рахунок нагромаджених страхових фрондів [1] }\end{array}$ \\
\hline
\end{tabular}

Джерело: складено автором.

страхування, який передбачає, згідно зі законом або договором, обов'язки страховика 3 оплати, включеної до програми страхування медичної, лікарської та профрілактичної допомоги, наданої застрахованій особі, за рахунок цільових фондів, сорормованих через кошти підприємств, органів влади і громадян.

Вивчення законодавчих актів України дає підстави засвідчити, що таке поняття, як «медичне страхування» у них відсутнє. У Законі України «Про страхування» зазначено, що медичне страхування може бути як обов'язковим, так і добровільним. Але тлумачення змісту та принципів медичного страхування немає. Лише у ст. 4 цього закону визначено, що медичне страхування $є$ різновидом особистого страхування [9].

Законодавче регулювання страхових правовідносин провадиться відповідно до норм Цивільного кодексу України, Господарського кодексу України, Закону України «Про страхування», Закону України «Про фрінансові послуги та державне регулювання ринків фрінансових послуг» та інших нормативно-правових актів України. Головні принципи обов'язкового медичного страхування закріплені в Законі України «Основи законодавства України про загальнообов'язкове державне соціальне страхування» [8].

У той же час, варто зазначити, що на сьогодні жодного нормативно-правового акта стосовно детального механізму реалізації медичного страхування в обов'язковій формі чинне українське законодавство не містить, тому нормативно-правове забезпечення медичного страхування потребує доопрацювання і вдосконалення.

Медичне страхування має об'єкт, предмет і суб'єкт страхової діяльності.

Н. С. Михайловська предмет медичного страхування, незалежно від форми, в якій воно здійснюється, визначає як «майнові інтереси, пов'язані з порушенням стану здоров'я застрахованої особи, а саме - витрати на отримання медичної допомоги або медичних послуг, зумовлених хворобою та втратою працездатності застрахованої особи» [6]. Об'єктом медичного страхування, на думку вченої, виступає життя і здоров'я громадян.

Щодо суб'єктів медичного страхування, то науковці висловлюють різні точки зору, зокрема Н. С. Михайловська вважає, що до них потрібно віднести: 1) страховика; 2) страхувальника; 3) органи державної влади та місцевого самоврядування; 4) застраховану особу; 5) медичні заклади; 6) сімейних лікарів; 7) асистуючі організації [5].

В. Д. Базилевич [1] та Д. Д. Третяк [15] включають до складу суб'єктів медичного страхування лише страховика, страхувальника, застраховану особу та медичні заклади.

Вважаємо, що доцільно класифікувати суб'єкти медичного страхування за прикладом Т. І. Сте- 
цюк та Н. Г. Нагайчук на основні, додаткові та контролюючі (рис. 1).

\begin{tabular}{|c|c|}
\hline \multicolumn{2}{|c|}{$\begin{array}{c}\text { КОНТРОлюючІ } \\
\text { Медичне страхове бюро } \\
\text { Держава в особі законодавчого та регулюючого органів }\end{array}$} \\
\hline$\Gamma$ & \\
\hline OCHOBHI & ДОДАТКОВІ \\
\hline $\begin{array}{c}\text { Страховики } \\
(\text { ФОНД, СМО)* }\end{array}$ & $\begin{array}{l}\text { Асистуючі } \\
\text { компанії }\end{array}$ \\
\hline $\begin{array}{l}\text { Страхувальники, } \\
\text { застраховані }\end{array}$ & $\begin{array}{c}\text { Органи ліцензування } \\
\text { СМО }\end{array}$ \\
\hline $\begin{array}{c}\text { Лікувально- } \\
\text { профрілактичні } \\
\text { установи (ЛПУ) }\end{array}$ & $\begin{array}{c}\text { Органи ліцензування } \\
\text { лпу }\end{array}$ \\
\hline
\end{tabular}

Puc. 1. Суб'єкти медичного страхування.

Примітка. * - ФОНД - фронд соціального страхування України; СМО - страхові медичні організації.

Джерело: складено автором на основі $[7,10]$.

Потрібно зауважити, що медичне страхування поєднує як економічні, так і соціальні фрункції. До економічних належать здійснення фрінансування охорони здоров'я, забезпечення захисту доходів громадян; перерозподіл коштів на оплату медичних послуг; підвищення конкуренції між медичними установами та рівня їх зацікавленості в наданні якісних медичних послуг. До соціальних фуункцій медичного страхування можна віднести здійснення охорони здоров'я громадян; розвиток медичного обслуговування; удосконалення ринку медичних послуг; підвищення економічного інтересу громадян до питань медичного забезпечення [3].

Медичне страхування класифрікують за різними ознаками. Так, відповідно до форми залучення застрахованих, медичне страхування поділяють на індивідуальне й колективне. Згідно з принципом управління, останнє поділяють на централізовану, децентралізовану та змішану форми. За характером фрінансування системи медичного страхування, виокремлюють бюджетну, соціальну, приватну і змішану фоорми. Відповідно до форми проведення, медичне страхування буває обов'язкове та добровільне $[1,6,7,12]$.

Обов'язкове медичне страхування (ОМС) виступає складовою системи соціального страхування та здійснюється за умовами і порядком, передбаченими законодавчим актом країни, відповідно до правил і базової програми обов'язкового медичного страхування, затвердженої урядом країни [4].

Добровільне медичне страхування (ДМС) - це вид особистого комерційного страхування, що використовує принцип страхової еквівалентності. Тобто, відповідно до договору добровільного медичного страхування, застрахований отримує тільки ті види медичних послуг і в такому обсязі, який покриває сплачена страхова премія. ДМС мінімально регламентується державою, зокрема у Законі України «Про страхування» визначено, що здійснення обов'язкових видів страхування, які не передбачені цим законом, забороняється [9].

Добровільне та обов'язкове медичне характеризуються як спільними, так і відмінними рисами. Так, до суттєвих відмінностей системи добровільного медичного страхування належать цілеспрямованість страхового внеску, що може бути використаним тільки в медичних цілях, і деяка обмеженість ролі держави, що за обов'язкового медичного страхування визначає перелік головних видів допомоги, коло застрахованих, величину страхового внеску, встановлює правила взаємодії всіх учасників сторін, здійснює контроль фрінансових потоків тощо, за цього не здійснюється регламентація зазначених питань для добровільного медичного страхування. Головна особливість обов'язкового медичного страхування полягає у тому, що ця форма страхування координується державними структурами та характеризується безприбутковістю. Страхові внески, що сплачують громадяни та юридичні особи, мають форму податку, тому стабільні - здійснюються відповідно до встановлених розмірів та у встановлений час, при цьому рівень страхового забезпечення $\epsilon$ однаковим для всіх застрахованих [5].

Інші, часом протилежні, характеристики має добровільна форма медичного страхування: не суттєво координується державою, страхові платежі сплачують застраховані особи добровільно, згідно з договором, відповідно, страхові організації отримують прибуток, але при цьому він не стабільний. Першопричиною появи ДМС стало те, що обсяг послуг й умови надання медичної допомоги за програмою ОМС обмежені.

Поряд із розбіжностями між добровільним i обов'язковим медичним страхуванням $є$ спільні риси. Зокрема, до останніх можна віднести однакову економіко-правову природу, а також мету здійснення, що свідчить про потребу застосування останніх в державі у вигляді паралельних систем захисту майнових інтересів зацікавлених осіб при настанні страхових випадків.

Сьогодні, коли нормативно-правова база, яка потрібна задля запровадження загальнообов'язкового державного соціального медичного страхування, - відсутня, добровільне медичне страхування відіграє допоміжну роль у забезпеченні населення медичною допомогою, а також виступає доповненням до обов'язкового. 
У результаті дослідження причинно-наслідкових зв'язків між станом здоров'я населення та провідними ризиками, що на нього впливають, визначено основні групи фракторів ризику за критерієм пріоритетного впливу: соціально-економічні індикатори розвитку економіки; стан екології; рівень розвитку охорони здоров'я та ризики, пов'язані з розповсюдженістю окремих захворювань і смертністю від них.

\section{Висновки}

За підсумками вивчення різних поглядів, представлених у науковій літературі, визначаємо медичне страхування як вид особистого страхування, який передбачає, згідно з законом або договором, обов'язки страховика з оплати, включеної до програми страхування медичної, лікарської та профрілактичної допомоги, наданої застрахованій особі, за рахунок цільових фрондів, сорормованих через кошти підприємств, органів влади і громадян.

Медичне страхування класифрікують у розрізі різних ознак. Як у світовій, так і в українській практиці виокремлюють дві головні форми медичного страхування, що характеризуються спільними та відмінними рисами: обов'язкове та добровільне медичне страхування.

Сьогодні система охорони здоров'я нашої країни перебуває не лише у фрінансовій, але й в організаційній кризі, що спричинена нерівномірним розподілом коштів та недостатнім рівнем надання медичної допомоги. Кроком до розв'язання проблем, що були означені у системі медичного забезпечення, може виступити проведення медичної реформи i, зокрема, впровадження загальнообов'язкового медичного страхування.

Перспективою подальших досліджень може бути проведення аналізу провідних ризиків, що впливають на здоров'я населення, вивчення динаміки та сучасного стану ринку медичного страхування, а також з'ясування особливостей медичного страхування в умовах пандемії. На основі аналізу рівня соціальних ризиків населення України можна обґрунтувати економічні та організаційні засади запровадження добровільного соціального медичного страхування.

\section{Список літератури}

1. Базилевич В. Д. Страхування : підручник / В. Д. Базилевич. - К. : Знання-Прес, 2008. - 1019 с.

2. Волохова Л. Ф. Медичне страхування та його розвиток в Україні / Л. Ф. Волохова, Д. О. Остапенко // Финансовые услуги. - 2017. - № 1. - С. 35-39.

3. Вороніна О. О. Наукові підходи до визначення сутності медичного страхування / О. О. Вороніна // Миколаївський національний університет імені В. О. Сухомлинського. - 2015. - № 8. - С. 733-737.

4. Державна політика у сорері охорони здоров'я : кол. моногр. : у 2 ч. / [кол. авт. ; упоряд. проф. Я. Ф. Радиш ; передм. та заг. ред. профр. М. М. Білинської, проф. Я. Ф. Радиша]. - К. : НАДУ, 2013. - Ч. 2. - 484 с.

5. Михайловська Н. С. Діяльність сімейного лікаря в умовах страхової медицини : навч.-метод. посіб. до практ. занять та самостійної роботи студентів VI курсу з дисципліни «Загальна практика - сімейна медицина» / Н. С. Михайловська. - Запоріжжя : ЗДМУ, 2017. - 109 с.

6. Михайловська Н. С. Організаційні основи загальної практики-сімейної медицини : навч. посіб. до практ. занять та самостійної роботи студентів VI курсу з дисципліни «Загальна практика - сімейна медицина» / Н. С. Михайловська. Запоріжжя : ЗДМУ, 2014. - 227 с.

7. Нагайчук Н. Г. Формування системи добровільного медичного страхування в умовах ринкової економіки : автореф. дис. на здобуття наук. ступеня канд. екон. наук : спец. 08.04 .01 «Фінанси, грошовий обіг і кредит» / Н. Г. Нагайчук. - К., 2006. - 22 с.

8. Основи законодавства України про загальнообов'язкове державне соціальне страхування : Закон України від 14.01.1998 р. № 16/98-ВР [Електронний ресурс]. - Режим доступу : http://zakon3.rada.gov.ua/laws/show/16/98$\% \mathrm{D0} \% \mathrm{~B} 2 \% \mathrm{D} 1 \% 80$.

9. Про страхування : Закон України від 07.03.1996 р. № 85/96-ВР [Електронний ресурс]. - Режим доступу : httр:// zakon3.rada.gov.ua/laws/show/85/96-211\%D0\%B2\%D1\%80.

10. Стецюк Т. І. Суб'єктна складова медичного страхування / Т. І. Стецюк // Ринок цінних паперів України. Вісник Державної комісії з цінних паперів та фрондового ринку. - 2009. - № 5-6. - С. 9-13.

11. Страхування: теорія та практика : навч. посіб. / Н. М. Внукова, Л. В. Временко, В. І. Успаленко та ін. ; за заг. ред. Н. М. Внукової. - 2-ге вид., переробл. та доповн. - Харків : Бурун Книга, 2009. - 656 с.

12. Страхование : учеб. для вузов / Л. А. Орланюк-Малицкая и др. ; под ред. Л. А. Орланюк-Малицкой, С. Ю. Яновой. 4-е изд. - М. : Юрайт, 2020. - 481 с.

13. Страхование : учеб. и практикум для прикладного бакалавриата / И. П. Хоминич и др. ; под ред. И. П. Хоминич, Е. В. Дик. - М. : Издательство Юрайт, 2016. - 437 с.

14. Страхование : учеб. для студентов / Ю. Т. Ахвледиани и др. ; под ред. Ю. Т. Ахвледиани, В. В. Шахова. - М. : ЮНИТИ-ДАНА, 2017. - 519 с.

15. Третяк Д. Д. Сутність та соціально-економічне значення медичного страхування / Д. Д. Третяк // Інвестиції: практика та досвід. - 2019. - № 12. - С. 43-47.

16. Шихов А. К. Страхование: организация, экономика, правовые аспекты : учеб. пособ. для вузов / А. К. Шихов. 2-е изд., перераб. и дополн. - М. : КУРС, ИНФРА-М, 2017. - 368 с. 


\section{References}

1. Bazylevych, V.D. (2008). Strakhuvannya [Insurance]. Kyyiv: Znannya-Pres [in Ukrainian].

2. Volokhova, L.F., \& Ostapenko, D.O. (2017). Medychne strakhuvannya ta yoho rozvytok v Ukrayini. [Health insurance and its development in Ukraine]. Fynansovye usluhy - Financial Services, 1, 35-39 [in Ukrainian].

3. Voronina, O.O. (2015). Naukovi pidkhody do vyznachennya sutnosti medychnoho strakhuvannya [Scientific approaches to defining the essence of health insurance]. Mykolayivskyy natsionalnyy universytet imeni V.O. Sukhomlynskoho V. Sukhomlinsky Mykolayiv National University, 8, 733-737 [in Ukrainian].

4. Bilynska, M.M., \& Radisha, J.F. (2013). Derzhavna polityka u sferi okhorony zdorovya [State policy in the field of health care]. Kyyiv: NADU [in Ukrainian].

5. Mykhaylovska, N.S. (2017). Diyalnist simeynoho likarya $v$ umovakh strakhovoyi medytsyny [The activity of a family doctor in terms of insurance medicine]. Zaporizhzhya: ZDMU [in Ukrainian].

6. Mykhaylovska, N.S. (2014). Orhanizatsiyni osnovy zahalnoyi praktyky-simeynoyi medytsyny [Organizational foundations of general practice-family medicine]. Zaporizhzhya: ZDMU [in Ukrainian].

7. Nahaychuk, N.H. (2006). Formuvannya systemy dobrovilnoho medychnoho strakhuvannya $v$ umovakh rynkovoyi ekonomiky [Formation of the system of voluntary health insurance in a market economy]. Extended abstract of candidate's thesis. Kyiv [in Ukrainian].

8. (1998). Osnovy zakonodavstva Ukrayiny pro zahalnoobovyazkove derzhavne sotsialne strakhuvannya: Zakon Ukrayiny vid 14.01.1998 №16/98-VR [Fundamentals of the legislation of Ukraine on compulsory state social insurance: Law of Ukraine of 14.01.1998 No 16 / 98-VR]. zakon3.rada.gov.ua. Retrieved from: http://zakon3.rada.gov.ua/laws/show/16/98\%D0\%B2\%D1\%80 [in Ukrainian].

9. (1996). Pro strakhuvannya: Zakon Ukrayiny vid 07.03.1996 №85/96-VR. [On insurance: Law of Ukraine of March 7, 1996 No 85 / 96-VR]. zakon3.rada.gov.ua. Retrieved from: http://zakon3.rada.gov.ua/laws/show/85/96-211\%D0\%B2\%D1\%80 [in Ukrainian].

10. Stetsyuk, T.I. (2009). Subyektna skladova medychnoho strakhuvannya [Subjective component of health insurance]. Rynok tsinnykh paperiv Ukrayiny. Visnyk Derzhavnoyi komisiyi z tsinnykh paperiv ta fondovoho rynku - Ukrainian securities market. Bulletin of the State Commission on Securities and Stock Market, 5-6, 9-13 [in Ukrainian].

11. Vnukova, N.M., Vremenko, L.V., \& Uspalenko, V.I. (2009). Strakhuvannya: teoriya ta praktyka [Insurance: theory and practice]. (Ed.) Vnukovoyi N.M. Kharkiv: Burun Knyha [in Ukrainian].

12. Orlanyuk-Malitskoy, L.A., \& Yanovoy, S.Yu. (2020). Strakhovaniye [Insurance]. Moscow: Yurayt Publishing House [in Russian].

13. Khominich, I.P. \& Dik, Ye.V. (2016). Strakhovaniye [Insurance]. Moscow: Yurayt Publishing House [in Russian].

14. Akhvlediani, Yu.T., \& Shakhova, V.V. (2017). Strakhovaniye [Insurance]. Moscow: UNITY-DANA [in Russian].

15. Tretyak, D.D. (2019). Sutnist ta sotsialno-ekonomichne znachennya medychnoho strakhuvannya [The essence and socio-economic significance of health insurance]. Investytsiyi: praktyka ta dosvid - Investments: Practice and Experience, 12, 43-47 [in Ukrainian].

16. Shikhov, A.K. (2017). Strakhovaniye: Organizatsiya, ekonomika, pravovyye aspekty [Insurance: Organization, economics, legal aspects]. Moscow: KURS: INFRA-M [in Russian].

\section{FEATURES OF HEALTH INSURANCE IN UKRAINE IN MODERN CONDITIONS}

N. Ya. Klymuk

I. Horbachevsky Ternopil National Medical University, Ternopil, Ukraine

Purpose: to find out the features of health insurance in modern conditions, taking into account the morbidity of the population.

Materials and Methods. Scientific articles of domestic and foreign scientists, directories of the State Statistics Service of Ukraine, reports of the Center for Public Health of the Ministry of Health of Ukraine and the Ministry of Health of Ukraine. During the implementation of this study, methods of structuring, analysis and generalization of information were used.

Results. In the article is systematized the scientific approaches to understanding the essence of the category «health insurance». To do this, an analysis of the legal framework, which provides health insurance regulation in Ukraine, as well as scientific literature. Based on this analysis, a comprehensive definition of the category «health insurance» are formed. The object, subject and subject of insurance activity are defined. The main features of compulsory and voluntary health insurance are outlined. The main groups of risk factors that affect the health of the population: socio-economic indicators of economic development; state of ecology; the level of health development and the risks associated with the prevalence and mortality of certain diseases. Based on the study, the main problems of health insurance development were identified: imperfect legal regulation, uneven distribution of funds and insufficient level of medical care. A step towards solving these problems in the health care system can be the implementation of medical reform, and, in particular, the introduction of compulsory health insurance.

Conclusions. Today, the health care system of our country is not only in financial, but also in organizational crisis, which is caused by uneven distribution of funds and insufficient level of medical care. The reform of health care, and in particular the introduction of compulsory health insurance, can be a step towards solving the problems identified in the health care system. 
KEY WORDS: health insurance; compulsory health insurance; voluntary medical insurance; medical insurance market.

Рукопис надійшов до редакції 15.01.2021 p.

\section{Відомості про автора:}

Климук Наталія Ярославівна - кандидат технічних наук, доцент кафедри медичної інформатики Тернопільського національного медичного університету імені І. Я. Горбачевського МОЗ України. 